\title{
Mechanism of Chloride Secretion Induced by Carbachol in a Colonic Epithelial Cell Line
}

\author{
Kiertisin Dharmsathaphorn and Stephen J. Pandol \\ Department of Medicine, University of California at San Diego; \\ and Veterans Administration Medical Center, San Diego, California 92103
}

\begin{abstract}
Serosal application of carbachol to $T_{84}$ cell monolayers mounted in an Ussing chamber caused an immediate increase in short circuit current $\left(\mathrm{I}_{\mathrm{sc}}\right)$ that peaked within $5 \mathrm{~min}$ and declined rapidly thereafter, although a small increase in $I_{s c}$ persisted for $\sim 30$ min. The increase in $I_{s c}$ was detectable with $1 \mu \mathrm{M}$ carbachol; half-maximal with $10 \mu \mathrm{M}$ carbachol; and maximal with $100 \mu \mathrm{M}$ carbachol. Unidirectional $\mathrm{Na}^{+}$and $\mathrm{Cl}^{-}$flux measurements indicated that the increase in $\mathrm{I}_{\mathrm{sc}}$ was due to net $\mathrm{Cl}^{-}$secretion. Carbachol did not alter cellular cAMP, but caused a transient increase in free cytosolic $\mathrm{Ca}^{2+}\left(\left[\mathrm{Ca}^{2+}\right]_{i}\right)$ from $117 \pm 7 \mathrm{nM}$ to $160 \pm 15 \mathrm{nM}$. The carbachol-induced increase in $I_{\mathbf{a c}}$ was potentiated by either prostaglandin $\mathrm{E}_{1}\left(\mathrm{PGE}_{1}\right)$ or vasoactive intestinal polypeptide (VIP), agents that act by increasing CAMP. Measurements of $\mathrm{CAMP}$ and $\left[\mathrm{Ca}^{2+}\right]_{i}$ indicated that the potentiated response was not due to changes in these second messengers. Studies of the effects of these agents on ion transport pathways indicated that carbachol, PGE 1 , or VIP each increased basolateral $\mathrm{K}^{+}$efflux by activating two different $\mathrm{K}^{+}$transport pathways on the basolateral membrane. The pathway activated by carbachol was not sensitive to barium, while that activated by PGE $_{1}$ or VIP was; furthermore, their action on $\mathrm{K}^{+}$efflux are additive. Our study indicates that carbachol causes $\mathrm{Cl}^{-}$secretion, and that this action may result from its ability to increase $\left[\mathrm{Ca}^{2+}\right]_{i}$ and basolateral $\mathrm{K}^{+}$efflux. Carbachol's effect on $\mathrm{Cl}^{-}$secretion is

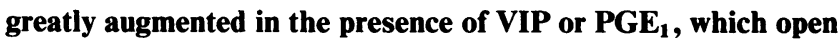
a cAMP-sensitive $\mathrm{Cl}^{-}$channel on the apical membrane, accounting for a potentiated response.
\end{abstract}

\section{Introduction}

Previous studies suggest that acetylcholine regulates intestinal ion transport (1-6). However, these studies were performed using intact mucosa or intestinal loops, and both tissues contain neuroendocrine elements $(2,3)$. In fact, findings that the cholinergic agent, carbachol, causes electrolyte absorption may be due to its ability to release adrenergic agonists from neural tissue in the gut and not due to a direct effect of carbachol on the intestinal epithelium (4).

In the present study, we sought to determine the direct cholinergic effect on intestinal epithelial transport by using a welldifferentiated colonic epithelial cell culture, the $T_{84}$ cell line. The advantages of studies with this cell line are that it contains

Address correspondence to Dr. Dharmsathaphorn. Received for publication 26 July 1985.

\section{J. Clin. Invest.}

(c) The American Society for Clinical Investigation, Inc.

0021-9738/86/02/0348/07 \$1.00

Volume 77, February 1986, 348-354 a single cell type and is devoid of neural elements and peptide hormones. Furthermore, monolayers of this culture allow accessibility of both the apical and the basolateral surface, giving precise localization for receptors and transport pathways. Our previous studies indicate that the $T_{84}$ cell line becomes well differentiated when grown to confluence on permeable supports. The resultant monolayers have a columnar epithelial appearance and retain receptor-mediated electrolyte transport mechanisms $(7,8)$. In particular, prostaglandin $\mathrm{E}_{1}\left(\mathrm{PGE}_{1}\right),{ }^{1}$ vasoactive intestinal polypeptide (VIP), carbachol, and A23187 cause increased short circuit current $\left(\mathrm{I}_{\mathrm{sc}}\right)$, and $\mathrm{Cl}^{-}$secretion (9-12). In addition, the $\mathrm{Cl}^{-}$secretion depends on the $\mathrm{Na}^{+}, \mathrm{K}^{+}, \mathrm{Cl}^{-}$co-transport, the $\mathrm{Na}^{+}, \mathrm{K}^{+}$-ATPase and $\mathrm{K}^{+}$efflux pathways on the basolateral membrane, as well as on a $\mathrm{Cl}^{-}$transport pathway on the apical membrane (9-14). Because the $\mathrm{Cl}^{-}$secretory processes are similar to those found in intact intestinal mucosa, we chose $T_{84}$ cell monolayers to study the mechanism of carbachol-induced $\mathrm{Cl}^{-}$ secretion in intestine.

\section{Methods}

Growth and maintenance of $\mathrm{T}_{\mathbf{8 4}}$ monolayers, transepithelial electrolyte transport studies, ${ }^{36} \mathrm{Cl}^{-}$uptake studies, ${ }^{86} \mathrm{Rb}^{+}$efflux studies, and measurement of cAMP follow similar procedures as described previously (9-11).

Free cytosolic calcium measurements. Monolayers were dispersed with $0.1 \%$ trypsin and $0.9 \mathrm{mM}$ EDTA in $\mathrm{Ca}^{++}$- and $\mathrm{Mg}^{++}$-free phosphatebuffered saline solution for $15 \mathrm{~min}$ at $37^{\circ} \mathrm{C}$, then washed with and incubated at $37^{\circ} \mathrm{C}$ in the cell culture medium in an untreated petri dish. In the untreated petri dish, the $T_{84}$ cell would not attach but would recover from the trypsinization procedure. After $18 \mathrm{~h}$, these dispersed cells were then loaded with Quin-2/AM in a solution containing $20 \mathrm{mM}$ Hepes (pH 7.4), $120 \mathrm{mM} \mathrm{NaCl}, 5 \mathrm{mM} \mathrm{KCl}, 1 \mathrm{mM} \mathrm{MgCl}_{2}, 0.5 \mathrm{mM}$ $\mathrm{CaCl}_{2}, 10 \mathrm{mM}$ glucose, $10 \mathrm{mM}$ pyruvate, $10 \mathrm{mM}$ ascorbate, $0.1 \%$ (wt/ vol) bovine serum albumin (fraction $\mathrm{V}$ ), $0.1 \%$ soybean trypsin inhibitor, and $50 \mathrm{mM}$ Quin-2/AM. They were incubated for $30 \mathrm{~min}$ at $37^{\circ} \mathrm{C}$ and then washed of extracellular Quin-2/AM with the same solution without Quin-2/AM and resuspended in the solution without Quin-2/AM. For measurement of free cytosolic calcium $\left(\left[\mathrm{Ca}^{2+}\right]_{i}\right)$, Quin-2 fluorescence was measured in $2.0-\mathrm{ml}$ aliquots of cell suspension in an Aminco-Bowman spectrofluoremeter with settings of $340 \mathrm{nM}$ excitation and $490 \mathrm{~nm}$ emission, and slit widths of $5.5 \mathrm{~nm}$ for excitation and $22 \mathrm{~nm}$ for emission. The cell suspension was continually stirred, maintained at $37^{\circ} \mathrm{C}$, and equilibrated for $\sim 5 \mathrm{~min}$ before the addition of the various agents. $\left[\mathrm{Ca}^{2+}\right]_{\mathrm{i}}$ was calculated using the following formula (15-19): $\left[\mathrm{Ca}^{++}\right]_{\mathrm{i}}=115 \mathrm{nM}$ $\left(F-F_{\min } / F_{\max }-F\right)$.

All fluorescence values were measured relative to the $\mathrm{MnCl}_{2}$-quenched signal (i.e., autofluorescence was subtracted from all values) that was determined as described below. $F$ was the relative fluorescence measurement of the sample. To determine maximum fluorescence $\left(F_{\max }\right)$, cells were lysed with sonication in the presence of $25 \mathrm{mM} \mathrm{CaCl}_{2}$, and

1. Abbreviations used in this paper: $\mathbf{I}_{\mathbf{s}}$, short circuit current; $P \mathrm{PGE}_{1}$, prostaglandin $E_{1}$; VIP, vasoactive intestinal polypeptide. 
relative fluorescence was measured. After determination of $F_{\max }, 1.0$ $\mathrm{mM} \mathrm{MnCl} 2$ was added to totally quench the Quin-2 signal. Minimum fluorescence $\left(F_{\min }\right)$ was calculated as $1 / 6 \times F_{\max }(19)$.

Materials. All radionuclides and cAMP antisera were obtained from New England Nuclear, Boston, MA. Carbachol came from ICN, Irvine, CA. PGE 1 was from Upjohn Co., Kalamazoo, MI. VIP was a gift from Dr. J. Rivier, The Salk Institute, La Jolla, CA. Bumetanide was a gift from Dr. P. Feit of Leo Pharmaceutical Products, Ballerup, Denmark. Barium chloride dihydrate was purchased from J. T. Baker Chemical Co., Phillipsburg, NJ. Quinidine was from Sigma Chemical Co., St. Louis, MO. Quin-2/AM was from Behring Diagnostics, La Jolla, CA.

Statistical analysis. $t$ tests were used as indicated (20).

\section{Results}

After $5 \mathrm{~d}$ or more in culture, $\mathrm{T}_{\mathbf{8 4}}$ cells, grown on the permeable, collagen-coated Nucleopore filters, appear as a columnar epithelial monolayers with their basolateral membrane firmly attached to the collagen-coated surface, and their apical membrane facing the medium (8). These monolayers maintained a transepithelial resistance of $\sim 1.5 \mathrm{~K} \Omega \mathrm{cm}^{2}$. The collagen-coated $\mathrm{Nu}$ cleopore filter, which served as the attachment support for the cells, had a resistance $<4 \Omega \mathrm{cm}^{2}$. Thus, the support contributed insignificantly to the transepithelial resistance. For electrolyte transport studies carried out in the modified Ussing chamber, we have denoted the basolateral membrane side as serosal side and apical membrane surface as mucosal side.

Stimulation of net $\mathrm{Cl}^{-}$secretion across $T_{84}$ monolayers by carbachol. The addition of $100 \mu \mathrm{M}$ carbachol to the serosal bathing solution caused an immediate increase in $I_{s c}$, which reached the peak within a few minutes after the addition. Thereafter, the $I_{s c}$ rapidly declined, reaching the baseline by $\sim 10 \mathrm{~min}$ (Fig. 1). Mucosal addition had little or no effect (data not shown). The action of carbachol could be totally inhibited by $100 \mu \mathrm{M}$ atropine (data not shown). The response was dose dependent, with $1 \mu \mathrm{M}$ carbachol causing detectable stimulation; $10 \mu \mathrm{M}$ carbachol causing half-maximal stimulation; and $100 \mu \mathrm{M}$ carbachol

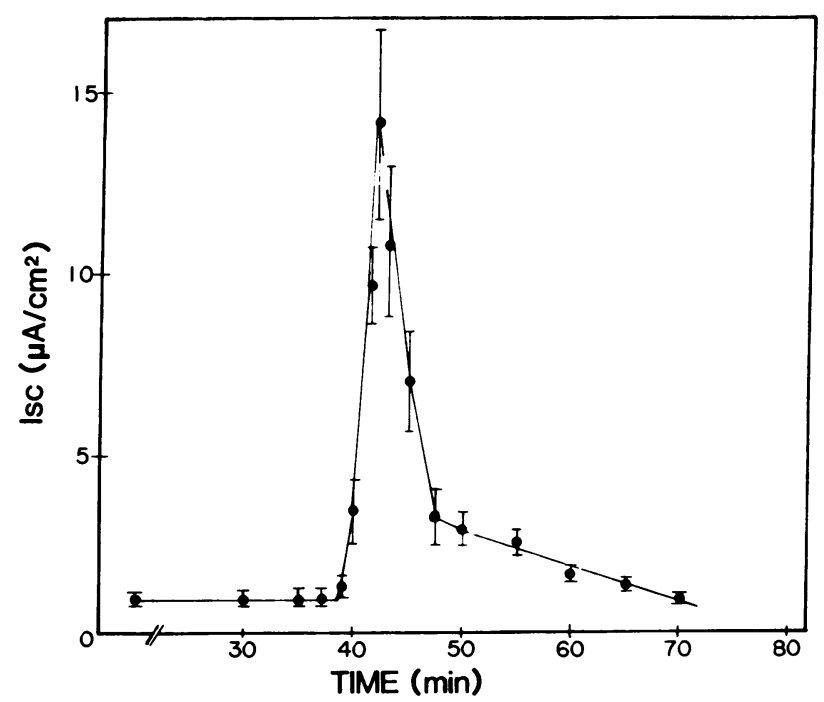

Figure 1. Time-course of the $\mathrm{I}_{\mathrm{sc}}$ response to $10^{-4}$ carbachol. Results are expressed as mean $\pm \mathrm{SE}$ of six monolayers. Addition of carbachol to the serosal surface resulted in an immediate increase in the $I_{x c}$, and reached a peak within $5 \mathrm{~min}$. Thereafter, the $I_{\mathbf{s c}}$ rapidly declined, but did not reach the baseline until $\sim 30$ min after the addition. causing maximal stimulation (Fig. 2). $100 \mu \mathrm{M}$ carbachol was therefore used in all subsequent studies.

Results of unidirectional $\mathrm{Na}^{+}$and $\mathrm{Cl}^{-}$fluxes are summarized in Table I. Previous studies demonstrated that net fluxes and $I_{s c}$ in the absence of added secretagogues remained constant at or near zero for $>100 \mathrm{~min}$ (9-12), and thus, each monolayer served as its own control in this study. After the addition of $100 \mu \mathrm{M}$ carbachol, serosal to mucosal flux of $\mathrm{Cl}^{-}$increased, while mucosal to serosal flux remained stable, resulting in net $\mathrm{Cl}^{-}$secretion. No effects were observed on the unidirectional or net $\mathrm{Na}^{+}$fluxes. Therefore, the carbachol-induced increase in $\mathrm{I}_{\mathbf{s c}}$ results from net $\mathrm{Cl}^{-}$secretion. Similar to the change in $\mathrm{I}_{\mathrm{sc}}, \mathrm{Cl}^{-}$secretion induced by carbachol in the $T_{\mathbf{8 4}}$ cells was also transient, lasting only $\sim 10$ min.

In isolated intestine, the effects of carbachol on $\mathrm{Cl}^{-}$secretion usually last $>10$ min (3-5). Because intestinal mucosa contains other potential secretagogues, such as $\mathrm{PGE}_{1}$ and VIP, we tested the possibility that the action of carbachol is potentiated by these agents using the $\mathrm{I}_{\mathrm{sc}}$ to quantitate $\mathrm{Cl}^{-}$secretion. In this study, we have demonstrated that the changes in $\mathrm{I}_{s c}$ reflect net $\mathrm{Cl}^{-}$secretion induced by carbachol. In other studies, we have demonstrated that $\mathrm{PGE}_{1^{-}}$and VIP-induced $\mathrm{I}_{\mathrm{sc}}$ also reflect net $\mathrm{Cl}^{-}$secretion $(11,12)$, including the potentiated response by VIP and A23187. We have further confirmed this fact by measuring $\mathrm{Cl}^{-}$secretion in the presence of both $\mathrm{PGE}_{1}$ and carbachol (average $\mathrm{I}_{\mathrm{sc}}$ increase in the first $10 \mathrm{~min}$ of $79 \pm 7 \mu \mathrm{A} / \mathrm{cm}^{2}$ or $1.48 \pm 0.13 \mu \mathrm{eq} / \mathrm{h} \cdot \mathrm{cm}^{2}$ approximated net $\mathrm{Cl}^{-}$secretion, which was $1.65 \pm 0.26 \mu \mathrm{eq} /$ $\left.\mathrm{h} \cdot \mathrm{cm}^{2}\right)$. Carbachol $(100 \mu \mathrm{M}), \mathrm{PGE}_{1}(10 \mu \mathrm{M})$, and VIP (10 nM) each caused a peak increase in $I_{s c}$ of $17 \pm 2,22 \pm 3$, and $22 \pm 6 \mu \mathrm{A}$ / $\mathrm{cm}^{2}$, respectively, at $5 \mathrm{~min}$ of incubation ( $n=5$ each). At $5 \mathrm{~min}$ incubation, the combination of $100 \mu \mathrm{M}$ carbachol with $10 \mu \mathrm{M}$ $\mathrm{PGE}_{1}$ or $10 \mathrm{nM}$ VIP caused a peak increase in $\mathrm{I}_{\mathrm{sc}}$ of $52 \pm 7$ and $68 \pm 9 \mu \mathrm{A} / \mathrm{cm}^{2}$, respectively ( $n=5$ each). Thus, the response with carbachol plus $\mathrm{PGE}_{1}$ or VIP was greater than the expected additive response $(P<0.05)$. More importantly, the potentiating response caused by $\mathrm{PGE}_{1}$ persisted in monolayers preincubated with carbachol for $>15$ min (Fig. 3). Similarly, VIP potentiated the carbachol response even when the monolayers were preincubated with $100 \mu \mathrm{M}$ carbachol for $30 \mathrm{~min}$. The increase in $\mathrm{I}_{\mathbf{s c}}$

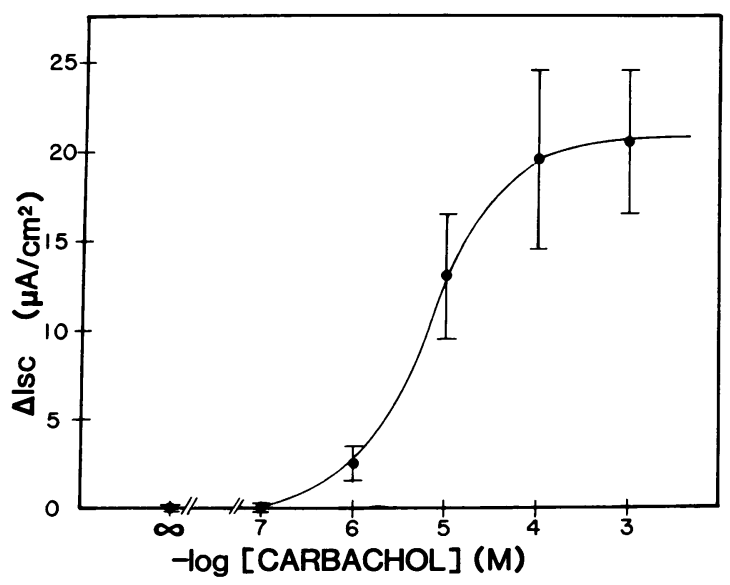

Figure 2. Graded dose effect of carbachol on the changes in $I_{\mathbf{s c}}$. Carbachol was added to the serosal reservoir in concentrations shown. The peak $I_{s c}$ that occured after the addition of carbachol was expressed as mean $\pm \mathrm{SE}$ of four monolayers in each group. Only one concentration was added to each monolayer. 


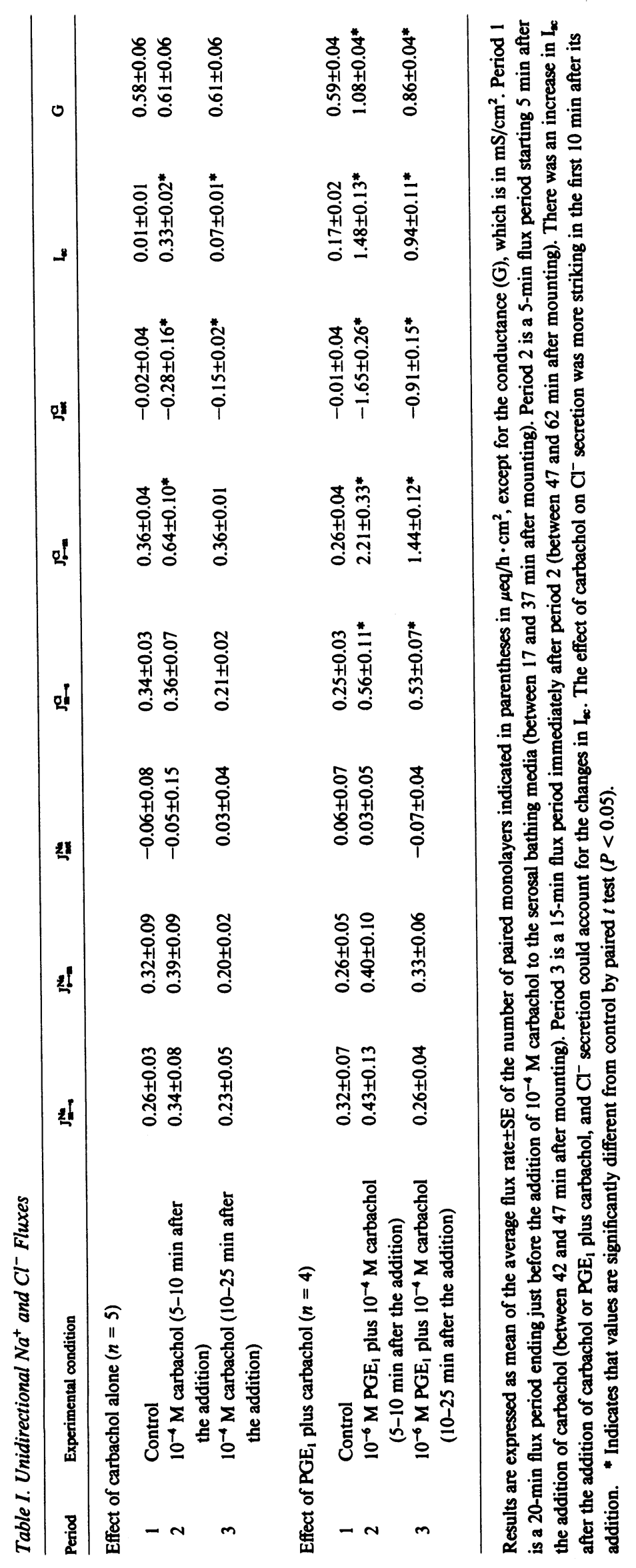




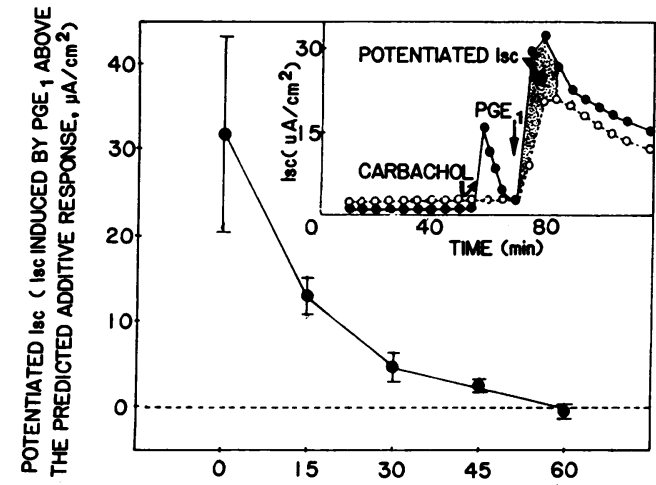

TIME DELAYED BETWEEN CARBACHOL AND PGE, ADOITION (min)

Figure 3. Potentiation of $\mathrm{PGE}_{1}$ response to carbachol. The potentiated $I_{x c}$ shown on the vertical axis is the average $I_{x c}$ induced by $P G E_{1}$ in carbachol pretreated monolayers above the predicted additive response. The time interval between the addition of carbachol followed by $\mathrm{PGE}_{1}$ is indicated on the horizontal axis. The average $I_{x c}$ was measured during the 15-min period after the addition of $P E_{1}$. From this value were subtracted the $P G E_{1}$-induced $I_{x c}$ during the same period when the monolayers were not pretreated with carbachol and the average $I_{x}$ induced by carbachol alone during this period. In the inset in the upper right hand corner is a figure representing this calculation. In this figure, carbachol was added to one monolayer (๑) $15 \mathrm{~min}$ before the addition of $P G E_{1}$ to both monolayers. Open circles indicate the effect of PGE, without carbachol pretreatment. The shaded area represents the potentiated response. We did not include the values for carbachol alone in this figure because they were near basal values. The results are expressed as mean $\pm \mathrm{SE}$ of four monolayers at each time point. The concentrations of carbachol and $\mathrm{PGE}_{1}$ were $10^{-4}$ and $10^{-6} \mathrm{M}$, respectively. The effect of $P E_{1}$ on carbachol-pretreated monolayers remained greater than the predicted additive response for $>15 \mathrm{~min}$.

with $10 \mathrm{nM}$ VIP in these carbachol-pretreated monolayers was $20 \pm 1 \mu \mathrm{A} / \mathrm{cm}^{2}$, while the increase by $10 \mathrm{nM}$ VIP in nonpretreated monolayers was $14 \pm 1 \mu \mathrm{A} / \mathrm{cm}^{2}$. These results indicate that carbachol potentiates the action of $P E_{1}$ and VIP on $I_{s c}$ even after the effect of carbachol alone on $I_{s c}$ dissipates. These findings may explain the more sustained action of carbachol in whole mucosa.

Inhibition of carbachol-stimulated $I_{s c}$ by bumetanide or barium. Previous studies demonstrated the existance of the $\mathrm{Na}^{+}$, $\mathrm{K}^{+}, \mathrm{Cl}^{-}$co-transport pathway and the $\mathrm{K}^{+}$channel, as well as their participation in the $\mathrm{Cl}^{-}$secretory process induced by cAMP ( $\mathrm{PGE}_{1}$ or VIP) or $\mathrm{Ca}^{++}$ionophore (A23187) in $\mathrm{T}_{84}$ monolayers (9-14). In addition, these studies also indicated that bumetanide and barium inhibit the $\mathrm{Na}^{+}, \mathrm{K}^{+}, \mathrm{Cl}^{-}$cotransport system and a $\mathrm{K}^{+}$channel, respectively. To identify the electrolyte transport pathways involved in the $\mathrm{Cl}^{-}$secretory process induced by carbachol, the effect of carbachol on the $I_{x c}$ was tested in the presence of these inhibitors. Bumetanide was used as an inhibitor for the $\mathrm{Na}^{+}, \mathrm{K}^{+}, \mathrm{Cl}^{-}$co-transport pathway, while barium was as an inhibitor for the $\mathrm{K}^{+}$channels. $\mathrm{Cl}^{-}$channels were not tested because we could not identify a suitable blocker for the $\mathrm{Cl}^{-}$channels in this cell line. As demonstrated previously for PGE $_{1}$ and VIP $(9,11)$, serosal application of $0.3 \mathrm{mM}$ bumetanide inhibited $\mathrm{Cl}^{-}$ secretion induced by carbachol (Fig. 4). This result suggests that the $\mathrm{Na}^{+}, \mathrm{K}^{+}, \mathrm{Cl}^{-}$co-transport serves as the $\mathrm{Cl}^{-}$uptake pathway on the basolateral membrane. In contrast to $\mathrm{PGE}_{1}$ or VIP (10, 11), the effect of carbachol was not inhibited by $6 \mathrm{mM} \mathrm{BaCl}$, but was inhibited by quinidine in a dose-dependent manner. Other putative $\mathrm{K}^{+}$channel blockers, including tetraethylam-

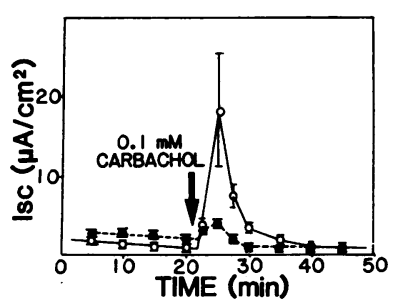

Figure 4. Inhibition of carbacholinduced $\mathrm{I}_{\mathrm{xc}}$ by bumetanide. Comparison of $I_{x}$ responses to $10^{-4} \mathrm{M}$ carbachol in control (O) and bumetanide- (๑) pretreated monolayers. $100 \mu \mathrm{M}$ bumetanide was added to the serosal side 5 min after mounting, and carbachol was added at 20 min. The results are expressed as mean $\pm S E$ of seven monolayers in the bumetanide group and three in the control group. Bumetanide almost completely inhibited the response to carbachol.

monium chloride (10 $\mathrm{mM})$, 4-aminopyridine (10 $\mathrm{mM})$, and apamin $(1 \mu \mathrm{M})$ had no effect on $\mathrm{Cl}^{-}$secretion induced by carbachol (data not shown). Such results indicate that the basolateral $\mathrm{K}^{+}$channel activated by $\mathrm{PGE}_{1}$ and VIP is not activated by carbachol.

Lack of influence by carbachol on Cl transport across the apical membrane. Previous studies demonstrated the existence of a $\mathrm{Cl}^{-}$transport pathway on the apical membrane of the $\mathrm{T}_{\mathbf{8 4}}$ cells that is stimulated by $\mathrm{PGE}_{1}$ or VIP, but not by $\mathrm{A} 23187$. Kinetic studies and preliminary patch clamp studies suggest that this pathway is a $\mathrm{Cl}^{-}$channel (reference 13, Frizzell, R. A., personal communication). According to these earlier studies, the activation of this $\mathrm{Cl}^{-}$exit pathway by peptides or neurotransmitters can be detected by a ${ }^{36} \mathrm{Cl}^{-}$uptake technique (13). In the present study, carbachol had no effect on ${ }^{36} \mathrm{Cl}^{-}$uptake across the apical membrane, while both $\mathrm{PGE}_{1}$ and VIP did increase ${ }^{36} \mathrm{Cl}^{-}$uptake (Figs. 5 and 6). Furthermore, the PGE ${ }_{1}$ and VIPinduced increases in ${ }^{36} \mathrm{Cl}^{-}$uptakes were not altered by carbachol (Fig. 6). Similar results were obtained in the absence of bumetanide or ouabain. At $1,2.5$, and $5 \mathrm{~min},{ }^{36} \mathrm{Cl}^{-}$uptakes in the presence and absence of $10^{-4} \mathrm{M}$ carbachol were $2.0 \pm 0.9,3.8 \pm 1.5$, and $3.3 \pm 1.1 \mathrm{nmol} / \mathrm{mg}$ protein and $1.8 \pm 0.7,3.8 \pm 0.5$, and $3.6 \pm 0.9$ $\mathrm{nmol} / \mathrm{mg}$ protein, respectively. Carbachol also did not alter the increase in ${ }^{36} \mathrm{Cl}^{-}$uptakes induced by VIP or $\mathrm{PGE}_{1}$ under this experimental condition. At $5 \mathrm{~min}, \mathrm{Cl}^{-}$uptakes were $6.9 \pm 1.9$ and $5.9 \pm 1.1 \mu \mathrm{mol} / \mathrm{mg}$ protein in the presence of $10^{-8} \mathrm{M}$ VIP and $10^{-6} \mathrm{MPGE}$, respectively. Similar results of $6.6 \pm 1.6$ and $6.0 \pm 1.1 \mu \mathrm{mol} / \mathrm{mg}$ protein, respectively, were obtained in the presence of $10^{-4} \mathrm{M}$ carbachol. These results suggest that the effect of carbachol on $\mathrm{Cl}^{-}$secretion is not a result of the opening of the cAMP-sensitive $\mathrm{Cl}^{-}$channels on the apical membrane, but rather a result of an increase in the driving force that may operate more efficiently once the cAMP-sensitive $\mathrm{Cl}^{-}$channel is opened. The lack of carbachol effect should be interpreted with some cautions. Our assay, which is suitable for detecting the opening of the cAMP-sensitive $\mathrm{Cl}^{-}$channels, may not detect the opening of $\mathrm{Ca}^{++}$-sensitive $\mathrm{Cl}^{-}$channels.

Evidence for carbachol-induced $\mathrm{K}^{+}$efflux on the basolateral membrane and its additive effect to $P G E_{1}$-induced $K^{+}$efflux. In a variety of epithelia, including $T_{84}$ monolayers, agents that increase $\mathrm{Cl}^{-}$secretion also cause an increase in basolateral membrane conductance to $\mathrm{K}^{+}$, which appears to be required to sustain the $\mathrm{Cl}^{-}$secretory process $(10,21,22)$. To test whether carbachol stimulates $\mathrm{K}^{+}$efflux across the basolateral membrane, monolayers were preloaded with ${ }^{86} \mathrm{Rb}^{+}$(as a tracer for $\mathrm{K}^{+}$) and mounted in the Ussing chamber. This allowed us to measure ${ }^{86} \mathrm{Rb}^{+}$efflux across both the apical and basolateral surfaces and the $\mathrm{I}_{s c}$, which reflects $\mathrm{Cl}^{-}$secretion, simultaneously. The results are shown in Table II. At the basal state, the rate of ${ }^{86} \mathrm{Rb}^{+}$efflux 


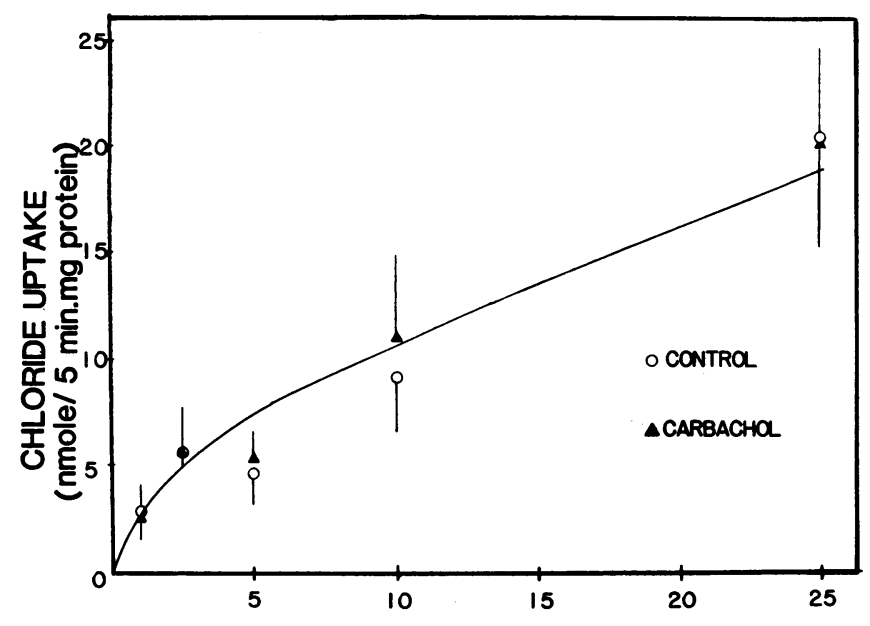

TIME (minutes)

Figure 5. Lack of effect of carbachol on ${ }^{36} \mathrm{Cl}^{-}$uptake across the apical membrane. Confluent monolayers grown on permeable supports similar to those used in the Ussing chamber were preincubated in $\mathrm{KCl}$ and sucrose-ouabain buffer as described previously (13). ${ }^{36} \mathrm{Cl}^{-}$uptake across the apical membrane was carried out in uptake buffer consisting of $140 \mathrm{mM} \mathrm{Na}$ gluconate, $20 \mathrm{mM}$ Tris-Hepes, $1 \mathrm{mM}$ Ca gluconate, $1 \mathrm{mM} \mathrm{Mg}$ gluconate, $0.5 \mathrm{mM}$ ouabain, $0.1 \mathrm{mM}$ bumetanide, and $1 \mu \mathrm{Ci} / \mathrm{ml}^{36} \mathrm{Cl}^{-}$(final concentration, $6 \mathrm{mM}$ ) with or without $10^{-4}$ $\mathrm{M}$ carbachol. An identical buffer, without added ${ }^{36} \mathrm{Cl}^{-}$, was added simultaneously to the basolateral side. Uptakes were carried out at the time intervals indicated on the horizontal axis at room temperature before terminating by dunk washing in four successive 1-liter containers of $\mathrm{Mg}$ gluconate-sucrose buffer. Results are the mean $\pm \mathrm{SE}$ of six monolayers at each time point. Carbachol had no effect on $\mathrm{Cl}^{-}$uptake under this experimental condition.

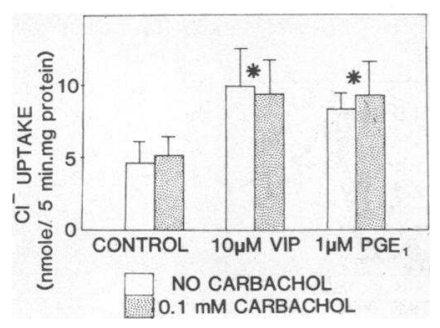

Figure 6. Lack of effect of carbachol on PGE $_{1}$ or VIP-stimulated ${ }^{36} \mathrm{Cl}^{-}$uptake across the apical membrane. Conditions for uptake studies are as described in Fig. 5. Results are mean $\pm \mathrm{SE}$ of $\mathrm{Cl}^{-}$uptake from five monolayers in each group. Results at $5 \mathrm{~min}$, when carbachol's action was at its peak, are shown. Astericks indicate $P<0.05$ by unpaired $t$ test as compared with control without VIP or PGE 1 . Carbachol does not alter the increased uptake stimulated by $\mathrm{PGE}_{1}$ or VIP.

into the mucosal bath was $\sim 10-20$-fold smaller than that into the serosal bath. The addition of carbachol (added to both sides) dramatically increased the rate of ${ }^{86} \mathrm{Rb}^{+}$efflux into the serosal bath for $\sim 10 \mathrm{~min}$. The rate of ${ }^{86} \mathrm{Rb}^{+}$efflux into the mucosal bath also increased during this initial $10 \mathrm{~min}$, although the magnitude of increase is quite small. These increases in ${ }^{86} \mathrm{Rb}^{+}$efflux occurred simultaneously with the increase in $I_{s c}$. The increase in basolateral membrane ${ }^{86} \mathrm{Rb}^{+}$efflux rate by carbachol was not inhibited by prior addition of $3 \mathrm{mM} \mathrm{BaCl}$, which completely inhibited $\mathrm{PGE}_{1}$ or VIP-stimulated ${ }^{86} \mathrm{Rb}^{+}$efflux. The results suggest that carbachol stimulated $\mathrm{K}^{+}$efflux across the basolateral membrane via a $\mathrm{K}^{+}$transport mechanism that is distinct from that involved in the action of $\mathrm{PGE}_{1}$ or VIP.

We then compared the magnitude of ${ }^{86} \mathrm{Rb}^{+}$efflux and the $\mathrm{I}_{\mathrm{sc}}$ (which reflects $\mathrm{Cl}^{-}$secretion) induced by carbachol, $\mathrm{PGE}_{1}$, or their combinations (Fig. 7). The carbachol-induced ${ }^{86} \mathrm{Rb}^{+}$ efflux was relatively large in magnitude as compared with that

Table II. ${ }^{86} \mathrm{Rb}^{+}$Efflux in Response to Carbachol

\begin{tabular}{|c|c|c|c|c|c|}
\hline \multirow[b]{2}{*}{ Period } & \multirow[b]{2}{*}{ Experimental condition } & \multicolumn{4}{|c|}{${ }^{20} \mathrm{Rb}^{+}$efflux rate constant } \\
\hline & & Mucosal & Serosal & $\mathrm{I}_{\boldsymbol{c}}$ & $\mathbf{G}$ \\
\hline & & $h^{-1}$ & $h^{-1}$ & $\mu e q / h \cdot \mathrm{cm}^{2}$ & $\mathrm{mS} / \mathrm{cm}^{2}$ \\
\hline \multicolumn{6}{|c|}{ Control $(n=3)$} \\
\hline 1 & No addition & $0.07 \pm 0.01$ & $0.59 \pm 0.11$ & $0.03 \pm 0.01$ & $0.6 \pm 0.2$ \\
\hline 2 & No addition & $0.03 \pm 0.01$ & $0.58 \pm 0.13$ & $0.06 \pm 0.03$ & $0.6 \pm 0.1$ \\
\hline 3 & No addition & $0.03 \pm 0.01$ & $0.48 \pm 0.02$ & $0.07 \pm 0.03$ & $0.6 \pm 0.1$ \\
\hline \multicolumn{6}{|c|}{$10^{-4} \mathrm{M}$ carbachol $(n=11)$} \\
\hline 1 & No addition & $0.09 \pm 0.01$ & $0.50 \pm 0.02$ & $0.07 \pm 0.02$ & $0.8 \pm 0.1$ \\
\hline 2 & Carbachol & $0.12 \pm 0.02^{*}$ & $1.99 \pm 0.10^{*}$ & $0.40 \pm 0.10^{*}$ & $0.8 \pm 0.1$ \\
\hline 3 & Carbachol & $0.05 \pm 0.01$ & $0.61 \pm 0.05$ & $0.13 \pm 0.03$ & $0.6 \pm 0.1$ \\
\hline \multicolumn{6}{|c|}{$3 \mathrm{mM} \mathrm{Ba}^{++}+10^{-4} \mathrm{M}$ carbachol $(n=3)$} \\
\hline 1 & $\mathrm{Ba}^{++}$ & $0.07 \pm 0.01$ & $0.39 \pm 0.05$ & $0.04 \pm 0.01$ & $0.7 \pm 0.1$ \\
\hline 2 & $\mathrm{Ba}^{++}+$carbachol & $0.16 \pm 0.03^{*}$ & $1.98 \pm 0.17^{*}$ & $0.56 \pm 0.15^{*}$ & $0.9 \pm 0.1$ \\
\hline 3 & $\mathrm{Ba}^{++}+$carbachol & $0.06 \pm 0.01$ & $0.63 \pm 0.05$ & $0.17 \pm 0.04$ & $0.6 \pm 0.1$ \\
\hline
\end{tabular}

The results are expressed as mean $\pm \mathrm{SE}$ of the number of experiments indicated in parentheses. The results were analyzed during three time intervals: period 1, 0-20 min; period 2, 20-30 min; and period 3, 30-45 min. $\mathrm{BaCl}_{2}$, when used, was added within 5 min after mounting, while carbachol was added at $20 \mathrm{~min} .{ }^{86} \mathrm{Rb}^{+}$effluxes were increased by carbachol with serosal effluxes being $\sim 10-20$-fold greater than mucosal effluxes. The carbachol-induced ${ }^{86} \mathrm{Rb}^{+}$effluxes were not affected by $\mathrm{Ba}^{++}$. ${ }^{*}$ Indicates significant difference from control values during the same time interval $(P<0.05)$ by unpaired $t$ test. 


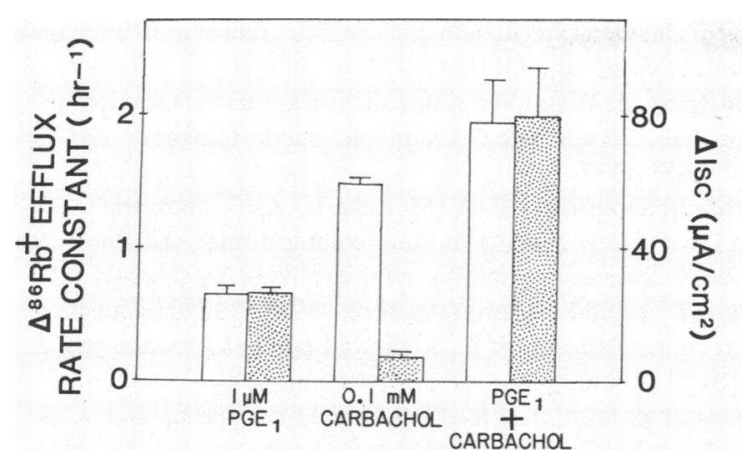

Figure 7. Comparison of ${ }^{86} \mathrm{Rb}^{+}$efflux across the basolateral membrane and $I_{s c}$. Results are expressed as mean \pm SE of 6-8 monolayers. Average changes in rate constant of ${ }^{86} \mathrm{Rb}^{+}$efflux per hour in the first 10 min after the addition of carbachol and/or $\mathrm{PGE}_{1}$ are expressed as clear bars, while changes in $\mathrm{I}_{\mathrm{sc}}$ represent changes in the rate of $\mathrm{Cl}^{-}$secretion, and are shown as solid bars. Basal rate constants for ${ }^{86} \mathrm{Rb}^{+}$efflux in the first $20 \mathrm{~min}$ were $0.48 \pm 0.04,0.56 \pm 0.06$, and $0.43 \pm 0.02$ in $P E_{1}$, carbachol, and $\mathrm{PGE}_{1}+$ carbachol groups, respectively, while basal $\mathrm{I}_{\mathbf{s c}}$ were $3 \pm 1,4 \pm 2$, and $1 \pm 1 \mu \mathrm{A} / \mathrm{cm}^{2}$, respectively. These basal values were subtracted from the observed responses to obtain the results shown in the figure.

induced by $P G E_{1}$, while its effect on $I_{s c}$ was relatively small. In contrast, the effect of $P G E_{1}$ on $I_{s c}$ was greater than that for carbachol. ${ }^{86} \mathrm{Rb}^{+}$efflux induced by the combination of carbachol and $P G E_{1}$ was additive, further supporting the presence of two different types of $\mathrm{K}^{+}$efflux pathways, one activated by $\mathrm{PGE}_{1}$ and another activated by carbachol. On the other hand, the increase in $\mathrm{I}_{\mathbf{s c}}$ induced by the combination of carbachol and $\mathrm{PGE}$ was greater than the additive response (potentiated). The above findings suggest that stimulation of $\mathrm{K}^{+}$efflux across the basolateral membrane alone by carbachol, without the opening of the cAMP-sensitive $\mathrm{Cl}^{-}$exit pathway on the apical surface, is a relatively ineffective means to stimulate $\mathrm{Cl}^{-}$secretion. Furthermore, these findings suggest that $\mathrm{PGE}_{1}$ and VIP potentiate the action of carbachol by opening the apical $\mathrm{Cl}^{-}$exit pathway, making $\mathrm{Cl}^{-}$secretion by carbachol more effective.

cAMP and free cytosolic $\mathrm{Ca}^{++}$measurements. To further explore the mechanisms of action of carbachol, PGE $_{1}$, and VIP, and the mchanism of action of potentiation, we measured the effects of these agents on cAMP and free cytosolic $\mathrm{Ca}^{2+}\left(\left[\mathrm{Ca}^{2+}\right]_{i}\right)$. The results are summarized in Fig. 8. Carbachol had no effect on cellular cAMP, while VIP and $\mathrm{PGE}_{1}$ both significantly increased cellular cAMP. The increase in cAMP by PGE $_{1}$ or VIP was not altered by carbachol. Carbachol increased $\left[\mathrm{Ca}^{2+}\right]_{i}$ from $117 \pm 7$ to $160 \pm 15 \mathrm{nM}$ within $1 \mathrm{~min}$ of addition. The increase was transient, such that $\left[\mathrm{Ca}^{2+}\right]_{i}$ returned to the basal concentration in $\sim 5 \mathrm{~min}$. The effect of carbachol was totally inhibited by $100 \mu \mathrm{M}$ atropine (data not shown). Both $\mathrm{PGE}_{1}$ and VIP had no effect on $\left[\mathrm{Ca}^{2+}\right]_{i}$, and neither one augmented the carbachol-induced changes in $\left[\mathrm{Ca}^{2+}\right]_{i}$. As a matter of fact, carbachol diminished the increments in cAMP concentration caused by VIP and $P E_{1}$. These results suggest that carbachol's action is mediated by an increase in $\left[\mathrm{Ca}^{2+}\right]_{i}$, while VIP's and PGE's actions are mediated by cAMP. In addition, the ability of VIP or PGE PG $_{1}$ to potentiate carbachol's effect on $I_{s c}$ cannot be explained by changes in either $\left[\mathrm{Ca}^{2+}\right]_{i}$ or cAMP alone.

\section{Discussion}

The use of a cultured intestinal cell line allows for the determination of the cellular mechanism involved in the action of

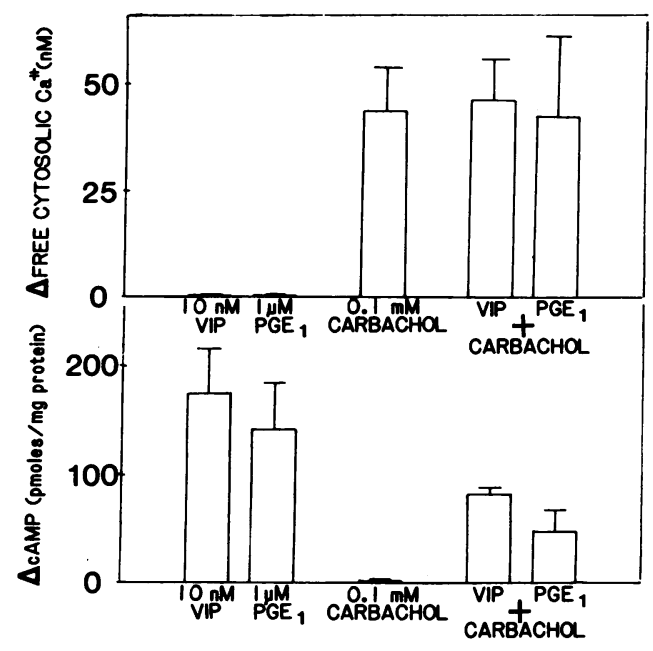

Figure 8. cAMP and free cytosolic $\mathrm{Ca}^{++}$in response to carbachol, VIP, and $\mathrm{PGE}_{1}$. cAMP was measured in monolayers similar to those using for Ussing chamber studies using New England Nuclear radioimmunoassay kits, while free cytosolic calcium was measured in dispersed $T_{84}$ cells as described in Methods. The results are expressed as mean \pm SE of the changes in cAMP or free cytosolic $\mathrm{Ca}^{++}$from 3 to 10 monolayers. For $\triangle \mathrm{cAMP}$, the changes were calculated from the cAMP level $15 \mathrm{~min}$ after stimulation by the agents indicated minus the basal cAMP, which was $5 \pm 1 \mathrm{pmol} / \mathrm{mg}$ protein. For free cytosolic $\mathrm{Ca}^{++}$, the values were calculated as the difference between the basal concentration and the peak concentration after the addition of the agent indicated. The average baseline level of free cytosolic calcium in these five groups was from $112 \pm 12$ to $125 \pm 11 \mathrm{nM}$. The increase in free cytosolic $\mathrm{Ca}^{++}$induced by carbachol was not altered by VIP or PGE . . Similarly, the increase in cAMP by VIP or PGE 1 was not altered by carbachol.

cholinergic agents as well as the interaction of cholinergic agents with other proposed secretagogues. The present study indicates that carbachol stimulates $\mathrm{Cl}^{-}$secretion from $\mathrm{T}_{84}$ cell monolayers. The response of $T_{84}$ monolayers resembles that occurring with isolated small intestine of animals and man, except that the effect is more sustained in isolated intestine (1-6). The difference may be due to the fact that intact mucosa contains neuroendocrine elements that also have effects on electrolyte absorption and secretion. Therefore, the results obtained with isolated intestine in part reflect the effect of endogenous agents. This notion is supported by the findings in the present study that carbachol pretreatment augmented the action of $\mathrm{PGE}_{1}$ and VIP.

Because carbachol stimulates an increase in $\left[\mathrm{Ca}^{2+}\right]_{i}$, and because A23187, the calcium ionophore, also causes $\mathrm{Cl}^{-}$secretion (12), our results suggest that carbachol's action on $\mathrm{Cl}^{-}$secretion is due at least in part to its effect on $\left[\mathrm{Ca}^{2+}\right]_{i}$. The ability of carbachol to cause $\mathrm{Cl}^{-}$secretion appears to involve $\mathrm{Cl}^{-}$uptake across the basolateral membrane via the $\mathrm{Na}^{+}, \mathrm{K}^{+}, \mathrm{Cl}^{-}$transport carrier and activation of a basolateral $\mathrm{K}^{+}$transport pathway. The activation of the latter pathway results in efflux of cellular $\mathrm{K}^{+}$. The $\mathrm{K}^{+}$efflux hyperpolarizes the cell to create a favorable electrical gradient for $\mathrm{Cl}^{-}$exit across the apical surface. That basolateral $\mathrm{K}^{+}$efflux is linked to apical $\mathrm{Cl}^{-}$secretion is substantiated by findings that $\mathrm{K}^{+}$channel blockers, such as barium, inhibit $\mathrm{Cl}^{-}$ secretion. Carbachol did not activate the apical $\mathrm{Cl}^{-}$channel in contrast to agents that act by increasing cellular cAMP such as $\mathrm{PGE}_{1}$ or VIP. The inability of carbachol to activate the apical $\mathrm{Cl}^{-}$channel may explain why carbachol is less effective in causing 
$\mathrm{Cl}^{-}$secretion than $\mathrm{PGE}_{1}$ or VIP, although their effects on $\mathrm{K}^{+}$ efflux and $\mathrm{Na}^{+}, \mathrm{K}^{+}, \mathrm{Cl}^{-}$cotransport are similar.

Our study indicates that another difference between carbachol and VIP or $\mathrm{PGE}_{1}$ is their effect on basolateral $\mathrm{K}^{+}$pathways. The $\mathrm{K}^{+}$pathway activated by carbachol is distinct from that activated by VIP and PGE 1 , as indicated by the following findings. First, carbachol's effect on ${ }^{86} \mathrm{Rb}^{+}$efflux is additive to that for VIP or $\mathrm{PGE}_{1}$. Second, barium, a $\mathrm{K}^{+}$channel blocker, inhibits ${ }^{86} \mathrm{Rb}^{+}$efflux stimulated by $\mathrm{PGE}_{1}$ or VIP, but has no effect on ${ }^{86} \mathrm{Rb}^{+}$efflux stimulated by carbachol.

Our findings suggest that the ability of $\mathrm{PGE}_{1}$ or VIP to potentiate the action of carbachol on $\mathrm{Cl}^{-}$secretion results from the differing effects of these agents on the ion pathways rather than on an increase in either cAMP or $\left[\mathrm{Ca}^{2+}\right]_{i}$. As indicated above, carbachol does not open the cAMP-sensitive $\mathrm{Cl}^{-}$channel on the apical membrane, so that $\mathrm{Cl}^{-}$secretion is limited, even though it is very effective in stimulating basolateral $\mathrm{K}^{+}$efflux. With the addition of $\mathrm{PGE}_{1}$ or VIP to carbachol-stimulated cells, the cAMP-sensitive $\mathrm{Cl}^{-}$channel on the apical membrane opens so that carbachol's effect on basolateral $\mathrm{K}^{+}$efflux can be effectively linked to $\mathrm{Cl}^{-}$secretion. In other words, $\mathrm{PGE}_{1}$ and VIP augment the action of carbachol on $\mathrm{Cl}^{-}$secretion by opening the apical $\mathrm{Cl}^{-}$gate, which is a rate-limiting step in carbachol's action, while their effect on $\mathrm{K}^{+}$efflux remains additive to that induced by carbachol, because they activate different $\mathrm{K}^{+}$transport pathways. The end result is the potentiated response on $\mathrm{Cl}^{-}$ secretion. Because the intestine contains prostaglandins, other arachidonic acid metabolites, and VIP (23-25), this integration between $\mathrm{PGE}_{1}$ or VIP and carbachol may also explain the more sustained response observed with cholinergic stimulus of intestinal mucosa compared with the more transient response we observed with $\mathrm{T}_{\mathbf{8 4}}$ monolayers.

\section{Acknowledgments}

The authors wish to thank Dr. James McRoberts for his helpful suggestions and his aid with a number of experiments. Ms. Bambi Beuerlein typed and edited the manuscript.

Dr. Dharmsathaphorn is a recipient of National Institutes of Health (NIH) research career development award AM 01146 and of an American Gastroenterological Association/Glaxo Research Scholar award. The study was supported by grants R01 AM 28305 and AM 33010 from the $\mathrm{NIH}$, a grant from the University of California Cancer Research Coordinating Committee, a grant from the Burroughs Wellcome Fund, and from the Research Services of the Veterans Administration Medical Center.

\section{References}

1. Hubel, K. A. 1976. Intestinal ion transport: effect of norepinephrine pilocarpine, and atropine. Am. J. Physiol. 231:252-257.

2. Paton, W. D. M., and M. Aboo Zar. 1968. The origin of acetylcholine released from guinea-pig intestine and longitudinal muscle strips. J. Physiol. 194:13-33.

3. Isaacs, P. E. T., C. L. Corbett, A. K. Riley, P. C. Hawker, and L. A. Turnberg. 1976. In vitro behavior of human intestinal mucosa. The influence of acetyl choline on ion transport. J. Clin. Invest. 58:535542.

4. Tapper, E. J., D. W. Powell, and S. M. Morris. 1978. Cholinergic adrenergic interactions on intestinal ion transport. Am. J. Physiol. 235: E402-E409.

5. Zimmerman, T. W., J. W. Dobbins, and H. J. Binder. 1983.
Mechanisms of cholinergic regulation of electrolyte transport in rat colon in vitro. Am. J. Physiol. 242:G116-G123.

6. Zimmerman, T. W., and H. J. Binder. 1983. Effect of tetrodotoxin on cholinergic agonist-mediated colonic electrolyte transport. Am. J. Physiol. 244:G386-G391.

7. Dharmsathaphorn, K., J. A. McRoberts, K. G. Mandel, L. D. Tisdale, and H. Masui. 1984. A human colonic tumor cell line that maintains vectorial electrolyte transport. Am. J. Physiol. 246:G204-G208.

8. Madara, J. L., and K. Dharmsathaphorn. 1985. Occluding junction structure-function relationships in a cultured epithelial monolayer. $J$. Cell Biol. 101:2124-2133.

9. Dharmsathaphorn, K., K. G. Mandel, H. Masui, and J. A. McRoberts. 1984. VIP-induced chloride secretion by a colonic epithelial cell line: direct participation of a basolaterally localized $\mathrm{Na}^{+}, \mathrm{K}^{+}, \mathrm{Cl}^{-}$ cotransport system. J. Clin. Invest. 75:462-471.

10. Mandel, K. G., J. A. McRoberts, G. Beuerlein, E. S. Foster, and K. Dharmsathaphorn. 1986. $\mathrm{Ba}^{++}$inhibition of VIP and A23187 stimulated $\mathrm{Cl}^{-}$secretion by $\mathrm{T}_{84}$ monolayers. Am. J. Physiol. In press.

11. Weymer, A., P. Huott, W. Liu, J. A. McRoberts, and K. Dharmsathaphorn. 1985. Chloride secretory mechanisms induced by prostaglandin $\mathrm{E}_{1}$ in a colonic epithelial cell line. J. Clin. Invest. 76:1828-1836.

12. Cartwright, C. A., J. A. McRoberts, K. G. Mandel, and K. Dharmsathaphorn. 1985. Synergistic action of cyclic AMP and calcium mediated chloride secretion in a colonic epithelial cell line. J. Clin. Invest. 76:1837-1842.

13. Mandel, K. G., K. Dharmsathaphorn, and J. A. McRoberts. 1986. Characterization of a cyclic AMP-activated $\mathrm{Cl}^{-}$transport pathway in the apical membrane of a human colonic epithelial cell line. J. Biol. Chem. In press.

14. McRoberts, J. A., G. Beuerlein, and K. Dharmsathaphorn. 1985. Cyclic AMP and $\mathrm{Ca}^{++}$activated $\mathrm{K}^{+}$transport in a human colonic epithelial cell line. J. Biol. Chem. 260:14163-14172.

15. Ochs, D. L., J. I. Korenbrot, and J. A. Williams. 1983. Intracellular calcium concentrations in isolated pancreatic acini: effects of secretagogues. Biochem. Biophys. Res. Commun. 117:122-128.

16. Tsien, R. Y. 1981. A non-disruptive technique for loading calcium. Nature (Lond.). 290:527-528.

17. Hesketh, T. R., G. A. Smith, J. P. Moore, M. V. Taylor, and J. C. Metcalfe. 1983. Free cytosolic calcium concentration and the mitogenic stimulation of lymphocytes. J. Biol. Chem. 258:4876-4882.

18. Rink, T. J., and R. Y. Tsien. 1982. Cytoplasmic free $\left[\mathrm{Ca}^{2+}\right]$ in very small intact cells. Biochem. Soc. Trans. 10:209. (Abstr.)

19. Rink, T. J., A. Sanchez, S. Grinstein, and A. Rothstein. 1983. Volume restoration in osmolarity swollen lymphocytes does not involve changes in free $\mathrm{Ca}^{2+}$ concentration. Biochim. Biophys. Acta. 762:593596.

20. Snedecor, G. W., and W. G. Cochran. 1967. Statistical Methods. Sixth ed. Iowa State University Press, Ames.

21. Shorofsky, S. R., M. Field, and H. A. Fozzard. 1982. The cellular mechanism of active chloride secretion in vertebrate epithelia: studies in intestine and trachea. Philos. Trans. R. Soc. Lond. 299:597-607.

22. Smith, P. L., and R. A. Frizzell. 1984. Chloride secretion by canine tracheal epithelium. IV. Basolateral membrane $\mathrm{K}$ permeability parallels secretion rate. J. Membr. Biol. 77:187-199.

23. Sharon, P., M. Ligumsky, D. Rachmilewitz, and U. Zor. 1978. Role of prostaglandins in ulcerative colitis. Enhanced production during active disease and inhibition by sulfasalazine. Gastroenterology. 75:638640.

24. Rampton, D. S., G. E. Sladen, and L. J. F. Youlten. 1980. Rectal mucosal prostaglandin $E_{2}$ release and its relation to disease activity, electrical potential difference, and treatment in ulcerative colitis. Gut. 21: 591-596.

25. Vaillant, C., R. Dimaline, and G. J. Dockray. 1980. The distribution and cellular origin of vasoactive intestinal polypeptide in the avian gastrointestinal tract and pancreas. Cell Tissue Res. 211:511-523. 